\title{
THIS
}

EDITORIALS

WORLD VIEW What Earth can learn from sci-fi classic Dunep.601
DISCOVERY Meet the multi-limbed squidworm $\mathbf{p . 6 0 2}$
OIL Robust report

rules on Deepwater

Horizon spill p.604

\section{An end to gridlock?}

\section{Europe says it is embarking on an unprecedented overhaul of its electricity system. But it must do more to convince the private sector that it is serious.}

$\mathrm{F}$ ew people care how their electricity is generated, as long as the lights come on when they press the switch. Even fewer care how it is delivered, which is why the growing problem of ageing energy infrastructure across Europe and the United States rarely gets the attention it deserves. A welcome exception to this attitude is the agreement to develop a new subsea electricity grid in the North Sea, which is due to be signed on 3 December by the energy ministers of ten European nations, including France, Germany and the United Kingdom.

Such an offshore grid would be a world first and would bring many benefits. These would include far greater integration, and hence price competition, between the electricity markets in northern Europe, wider access to extensive short-term hydropower storage in Norway, and crucial links to bring to land the energy generated by offshore wind, wave and tidal power. The grid is just one of half-a-dozen energy-infrastructure priorities for Europe that the European Commission announced last month. Together, they will require $€ 200$ billion (US\$264 billion) of investment over the next decade according to the commission, half of it from public sources. The quoted price for the North Sea grid is about $€ 20$ billion.

Other parts of the world face similar infrastructure challenges: in the United States, for example, a consortium led by Google has proposed a \$5-billion offshore grid to access offshore wind power and shore up the creaking electricity grid of the US eastern seaboard. A report from the American Physical Society last month pointed out that most US states don't yet have the necessary grid in place to handle the renewable capacity that they have committed to build.

Tomorrow's expected agreement, a memorandum of understanding on the North Sea grid, is only a small step towards its actual construction. In Europe as elsewhere, the high financial stakes associated with different energy projects can leave the real agendas unspoken, which makes energy policy a difficult political game to read.

In this case, the sustenance and development of nuclear energy may be a higher priority, to varying extents, for the centre-right governments led by David Cameron in Britain, Angela Merkel in Germany and Nicolas Sarkozy in France, than the rapid development of the renewable energy sources associated with the North Sea grid - although all three governments would be reluctant to say so in public.

In signing the memorandum, the European governments involved at least acknowledge that market forces alone cannot be expected to gain the infrastructure investments that Europe needs if it is to secure its electricity supplies and meet its carbon-emissions targets. Until quite recently, many political leaders continued to insist that all that was really needed to build energy infrastructure was the efficient distribution of private finance. They argued, fatuously, that 'markets would decide' which energy sources were appropriate and what infrastructure was needed. The reason that argument breaks down is that private investment in the energy sector depends heavily on rules and expectations set by governments. Decisions about where to build power lines, especially international ones, are ultimately political. And the availability of grid capacity will determine, to a considerable degree, which power sources are best placed to generate economically viable electricity. If Europe had relied entirely on the private sector to plan, build and finance existing electricity grids half a century ago, it would not have a functioning grid at all. If Europe relies on private finance for its future grid development,
"Market forces alone cannot be expected

to secure the infrastructure investments that Europe needs." it will end up with something more like the blackout-prone electricity grid of the United States, which has been starved of public investment for decades.

Future grid development also requires research and development, much of it in areas that have received little attention in recent decades (see page 624). To lower costs and increase efficiency, subsea grids will need technologies such as high-voltage d.c. converters and control systems. Research institutions such as the University of Strathclyde in Glasgow, UK, which is planning a $£ 100$-million (US\$157-million) centre devoted to innovation and renewable energy, can help to provide the knowledge needed to underpin these technologies.

To raise private money for new energy infrastructure and so control public costs, governments must send strong and consistent signals about their intentions. A deadline for countries involved in this project to revise their regulatory regimes to allow them to trade electricity would be a good start. The end result will be lower emissions, lower electricity costs for consumers, and the lights staying on as Europe embarks on an unprecedented overhaul of its power system.

\section{A long way to go Overpriced and underused, the International Space Station could still be a research asset.}

$\mathrm{H}$ anded US $\$ 100$ billion to spend on research, few scientists would invest in a cramped laboratory in constant need of maintenance with few facilities and one hell of a commute. So it is worth stating the obvious up front: the International Space Station (ISS) is an expensive, wasteful and probably unnecessary way to conduct science. The value of research carried out on the station will almost certainly never justify its ludicrous price tag. The money could surely have been put to better use on Earth.

But would it have been? Construction of the space station was never really about science, and researchers should think twice before continuing to use the project's epic cost as a stick with which to beat it. In 